sent by surface mail to those members in Africa, Europe, Asia, Australia and South America unless they are willing to pay for airmail as pointed out within the 1982 membership notices: to receive ASA materials by airmail, those members outside North America must pay $\$ 80.00$. If you wish to receive your journals by airmail, please remit $\$ 50.00$ by a check drawn on a U.S. bank or International Money Order. This will bring the total you are paying for your ASA membership to the $\$ 80.00$ required for you to receive your journals by airmail.

\title{
“Soak the Rich":
}

To: ASA Executive Sec'y,

From: G. Brooks, History Department, Indiana University

I believe that current dues are inequitable and especially unfair for students and faculty in lower ranks. . . As things stand now, an Assistant or Associate Professor making less than $\$ 20,000$ pays only $\$ 10.00$ less than a Full/Super Professor making over $\$ 30$ (or $\$ 40$ ) thousand a year, hardly a fair proposition. Many of the members of the Association are Full Professors and can pay more to support a more equitable dues structure. Good luck soaking us rich/those better able to contribute to the Association's activities. Trust you enjoyed your visit to Inner-Indiana.

Ed note: Inner Indiana was splendid.

\section{"Lonely Africanist" Protests "Elitist” ASA:}

Ed note: The followng note was carried in the newsletter of the Pacific Coast Africanist Association, edited by Ernest Valenzuela.

ASA Annual Meeting: The 24th meeting of the African Studies Association was held at Indiana University in October. Personally $I$ hope that the annual meeting was a great success and that it was well attended by many interested Africanists. I was not one of them and I wish I could have been. I was to have been on a panel, but had to cancel out. I could have dug deeper into my debt ridden pocket and pulled out the several hundred it would have cost to be in Bloomington, but my wife and my priorities reminded me of other more pressing needs like school tuition and Christmas that were in need of financial servicing by my over-extended paycheck.

Now I hope that I do not sound like a bad sport, but I'd like to state a point or two about the future of ASA and its annual conferences. First, lets hold them in cities where competitive air fares are available. It is certainly getting expensive to fly around to New York, Washington etc., let alone trying to find the way to San Jose or Bloomington. Let's limit future ASA meetings to major cities in the USA.

Second, might ASA consider hosting regional meetings one year and a national gathering the next. This is being done by a number of national organizations, with pretty good results. I feel this approach would bring the ASA closer to more of its members and give greater exposure to this fine organization. Let the ASA Directors select for themselves where to meet for their business meeting, possibly rotating among the regional gatherings. Any crucial votes could be done by mail in the year of regional meetings. This might even prove to be more "democratic" since few members attend the business meeting at the present conferences anyway. As an aside, I feel personally that much of my dues to ASA are going to take care of things that are of no real direct value to me and even possibly encouraging the development of a rather "elitist" approach to the Association. (ie. my dues going to put on a big meeting I cannot afford to attend or publishing materials that may be needed by collectors of highly specialized publications, but of no 
use to me as a Community College generalist.) I guess what I am saying is that ASA is not meeting my needs as a very "minor league" and "lonely" Africanist - thus my $\$ 40$ or so $\$ \$$ went towards tennis balls, instead of ASA dues, this past year.

Finally, might the ASA consider videotaping or even audio taping a few of the "stars" of ASA meetings, as they present their findings and make them available to Africanists, schools, regional meetings and conferences. Also it might be a way to share information and stimulate attendance at the more local gatherings of Africanists.

\section{MEETINGS PAST AND FUTURE}

International Third World Legal Studies Association (INTWORLSA). Annual membership meeting and panel discussion, Penn Center, Philadelphia (January 9, 1982). For information and membership contact: Professor James C.N. Paul, INTWORLSA, c/o International Center for Law in Development, 777 United Nations Plaza, New York, New York 10017.

Eleventh Annual Communications Conference. Howard University, Washington, D.C., 20059, Main Campus (February 18-21, 1982). Theme: "The Future of Communications: A Battle for the Human Mind."

Ninth Annual National Conference on the Black Family in America. Louisville Inn, Louisville, Kentucky (March 11-13, 1982). Sponsored annually by the Pan-African Studies Department of the University of Louisville. Contact: Dr. Joseph $\mathbf{H}$. McMillan, Conference Coordinator, Assistant Vice President-Affirmative Action/ Minority Affairs, University of Louisville, Louisville, Kentucky 40292, (502) 588-6678.

First Annual Conference of the Sudan Studies Association. Morgan State University, Baltimore, Maryland (March 26-27, 1982). For information about papers and panels contact: Dr. Ahmed E. El Bashir, History Department, University of the District of Columbia, Washington, D.C. 20008.

Eighth International Conference of the Society for Intercultural Education, Training and Research. R.M.S. Queen Mary, Long Beach, California (March 26-31, 1982). Theme: "Strategies for Cultural Stability and Change." Contact: SIETAR 1982 Conference, 1414 22nd St., N.W., Suite 102, Washington, D.C. 20037.

Annual Spring Meeting of the Association of African Studies Programs. Washington (April 1-2, 1982). Contact: Bob J. Walter, Association of African Studies Programs, 56 East Union Street, Athens, Ohio 45701.

Annual Meeting of the Western Association of Africanists. Utah State University, Logan, Utah (April 2-3, 1982). Contact: Dr. Sami Hajjar, Department of Political Science, University of Wyoming, University Station Box 3192, Laramie, Wyoming 82071, (307) 766-5345.

Third Annual Berkeley-Stanford Joint Center Conference on African Studies. Standford campus (April 10, 1982). For information and submission of abstracts: Cynthia Bass, Coordinator, Joint Center for African Studies, Institute of International Studies, University of California, Berkeley, CA 94720. 